\title{
Potential Risk Assessment of Cyanotoxin for Water Resources
}

\author{
Brajesh K. Dwivedi* \\ Environmental Sciences, Botany Department, University of Allahabad, \\ Allahabad- 211 002, India \\ *Corresponding author
}

\begin{tabular}{|l|}
\hline Ke y w or d s \\
$\begin{array}{l}\text { Surface water } \\
\text { quality, Cyanotoxin, } \\
\text { Hazard quotient, } \\
\text { Human heath }\end{array}$ \\
\hline Article Info \\
\hline $\begin{array}{l}\text { Accepted: } \\
\text { 28 December } 2017 \\
\text { Available Online: } \\
\text { 10 February } 2018\end{array}$ \\
\hline
\end{tabular}

A B S T R A C T

The presence of Blue-green algae (BGA) toxins in surface water sources and recreation is receiving increasing attention around the world as a public health concern. However, potential risks from exposure to these toxins in contaminated health food products that contain BGA have been largely ignored. Toxic BGA produces compound called microcystin. Fine-grained sediment is a natural and essential component of river systems and plays a major role in the hydrological, geo-morphological and ecological functioning of rivers. These complex nutrient influx increases pollution in the frequency and severity of toxic algae blooms in freshwater river has been a major concern for small communities that rely on them for drinking water supply. The present investigation observed the potency of bi-toxin (Cyanotoxin) in surface water reservoir and also the applications of the method for risk assessment and mitigation for five case studies, including Rasoolabad Ghat, Daraganj Ghat, Ram Ghat, Sangam and Chhatnag Ghat, Allahabad city. A hazard quotient approach to risk characterization is employed to analyze the effectiveness of treatment methods for removal of cyanotoxins, in addition to in-water reservoir (possibly through sediments reduction) as part of a suite of approaches, for restoration of eutrophic reservoir in general and running water for no risk of cyanotoxin.

\section{Introduction}

The presence of toxic cyanobacteria (BGA) in surface waters used for drinking water sources and recreation is receiving attention worldwide as a potential health concern. The study of rivers' water quality is extremely important. This issue is more important when the rivers are one of the main sources of water supply for drinking, agriculture, and industry. Unfortunately, river pollution has become one of the most important problems in the environment (Benedini and Tsakiris, 2013). When a source of pollution is trans-fused into the river, due to molecular motion, turbulence, and non-uniform velocity in cross section of flow, it quickly spreads and covers all around the cross section and moves along the river with the flow (Holzbecher, 2012; Chanson, 2004). Defining the mechanism of pollutant transmission in various types of rivers' geometry helps reduce the effects of water pollution on public health in human societies. Agricultural non-point source pollution 
combined with global warming have caused major algal blooms in our freshwater rivers and lakes (Asnaashari et al., 2015; Stang et al., 2016; Gazendam et al., 2016). Cyanobacteria are photosynthetic prokaryotes that thrive well in various kinds of habitats ranging from freshwater and other water reservoir (Duy et al., 2000; Ballot et al., 2003, 2010; Baxa et al., 2010; Bogialli et al., 2013; Chia et al., 2009, Chia and Kwaghe, 2015). They are popularly referred to as blue-green algae but their physiological, morphological and metabolic structures clearly identify them as bacteria. The photosynthetic origin of cyanobacteria is similar to that of algae but the pigments are located in the thylakoids, which is in the cytoplasm (Chorus et al., 2000; Codd et al., 2005; Drabkova and Marsalek, 2007; Ostermaier and Kurmayer, 2010; Echenique et al., 2014; Sayyad et al., 2015).

Conventionally bio-logically treated sewage water may not meet the require-ments for the discharge and permissible limit of wastewater for its reuse. These processes are, therefore, being ruled out due to requirement of large space, long residence time and skilled technicians. However, even after treatment, sec-ondary treated sewage (STS) effluent contains organic matter and nutrients which cause eutrophication and increase the oxygen demand of the surface water (Dwivedi and Pandey, 2017a). Sewage treatment deserves ample documentation due to the environmental impact caused by such wastewater if directly discharged into water bodies. Cyanobacteria have many properties which result in their relative success and predominance during the blooming season. The following factors are responsible for cyanobacteria blooms in aquatic habitat: aquatic temperatures above $25^{\circ} \mathrm{C}$, low light intensity in water, and low nitrogen-tophosphorous ratios (Hans and Timothy, 2013; Heisler et al., 2008; Hrudey et al., 1999; Griffiths and Saker, 2003; Kaushik and
Balasubramanian, 2013; Paerl et al., 2011; Tencalla and Dietrich, 1997). Presently, there about 3000 known species of cyanobacteria but not all produce toxins. Due to the increasing numbers of cases of cyanobacteria blooms, the occurrence of several harmful cyano-toxins in water supplies has also increased. There is growing concern about the potential for negative health effects on humans due to these toxins (Keijola et al., 1989; Baker et al., 2015; Makarewicz and Lewis, 2015; Merel et al., 2012; Mohamed et al., 2015).

Not-withstanding the recent scientific and technical advances in drinking water treatment plants around the globe, the concentrations of cyanobacterial-toxins have been reported to increase in treated drinking relative to raw water source for small water treatment plants. These toxins enter water supplies after lysis of cyano-bacterial cells, as induced by water collection and treatment activities resulting in subsequent release of toxins in finished treated waters. The toxins released by blue-green algae cannot be removed by conventional treatment methods (Merel et al., 2010; Newcombe and Nicholson, 2002; Nicholson et al., 2003; Szlag et al., 2015; Westrick et al., 2010; Zamyadi et al., 2012).

Drinking water treatment processes may cause breakthrough of toxins into treated drinking water as demonstrated by Zamyadi et al., (2012) in a full-scale water treatment plant system. The passage of toxins, toxic cells and cell debris through filtration systems inhibited chlorination that resulted in the breakthrough of microcystins, resulting in exceedance of Canadian and WHO water quality standards for treated drinking water. Long-term consumption of water contaminated by cyanobacteria and algae is known to cause liver failure, cardiac arrhythmia, dysfunction of the nervous system and skin tumors (Ontario Health Unit, 2014; Farrer et al., 2015). 
The objective of this study is to evaluate the use of conventional treatment options and riverbank filtration for managing cyanotoxins, to assess the vulnerability of existing municipal drinking water facilities using surface water sources. In addition, due to an increase in the scarcity of clean water, there is an urgent need for proper management of available water resources.

\section{Materials and Methods}

\section{Study area}

The holy city of Allahabd is surrounded by rivers in three directions i.e. river Ganga in north \& in east and by river Yamuna in south. Situated in the north west on confluence of two of India's holiest rivers, the Ganga and the Yamuna on the $25028^{\prime}$ 'north latitude and 81052 ' east longitude. The application of the hazard index is demonstrated for five case studies there water are supply to the river bank site of the city residential area, including Rasoolabad Ghat, Daraganj Ghat, Ram Ghat, Sangam and Chhatnag Ghat. Rasoolabad Ghat (Site 1) - This sampling site is situated at upstream where the river enters into the domain of city of Allahabad. The sources of pollution at this site are cremation, disposal of untreated sewage, washing of clothes, agricultural runoff and temple's solid waste disposal etc. Daraganj Ghat (Site 2)- It is situated at downstream of Rasoolabad Ghat, on the left bank of the river. This site is known for having big and glorious temples on its bank. Many drains like Salori drain, Govindpur drain, and Mori drain find their way directly near to this site. Other sources of pollution at this site are cattle wallowing, agricultural runoff, mass bathing, dhobi ghat and flower offerings etc. Ram Ghat (Site 3)This site is situated at downstream of Daraganj Ghat, on the left bank of the river. This site is also known for having many big temples. The main sources of pollutionat this site are open drains carrying untreated domestic sewage from Jhunsi area, religious fairs on its bank, garlands and flower offerings. Sangam (Site 4)- This site is situated at the confluence point of River Yamuna, Ganga and invisible Saraswati. Because of this rare occurrence, this site is known for the huge fair 'KumbhMela' organized every year due to it's great religious value. People from all over the world come here to have a holy dip. Main source of pollution at this site are mass bathing, flower offerings, cremation activities and religious fairs. Chhatnag Ghat (Site 5)- At this site river leaves the city and carries water of both the rivers Yamuna and Ganga. This site is situated at the downstream of river Ganga after the Sangam. This site is also used as the crematorial ground. Cattle wallowing are a common picture here. This site also receives untreated sewage and agricultural run-off.

\section{Water sampling procedures}

Samples were analyzed for selected variables by following the standard procedures (APHA, 2010). The periodic samplings were carried out in monsoon, winter and summer seasons with three replicates in June, 2016 to May, 2017. The site of sampling is selected randomly by considering the population, location and source of pollutions and supply source for the society. Due to variations in the species, concentrations and locations of cyanotoxins, appropriate analytical methods are required in order to understand the abundance and occurrence and the potential toxicity of cyanobacterial populations, and to effectively assess the risk of cyanotoxins to humans in drinking water supplies (Dwivedi and Pandey, 2001; Pandey and Dwivedi, 2002; Dwivedi and Pandey, 2002a,b; Dwivedi and Pandey, 2003a,b; Dwivedi et al., 2012; Kutovaya and Watson, 2014; Dwivedi and Srivastava, 2015; Dwivedi and Pandey, 2015; Dwivedi, 2016a,b,c,d). Data for small drinking 
water treatment plants in all selected site of river Ganga are adapted from different literature before, and after conventional treatment. Data are collected and monitored on a seasonally basis for the raw water samples from these plants; the changing characteristic of the toxins in the raw water and treated drinking water are the major foci for the drinking water data collected.

Table 3 lists the concentrations of cyanotoxins in raw and treated water for the selected study regions. The data in Table 2 are in agreement with the removal efficiencies of Cyanotoxins using the conventional treatment range from 25 to $99 \%$. Apart from Ram Ghat in Table 3, the concentrations of cyanotoxins in the raw water for all other locations are above the WHO guidelines for microcystins in drinking water. Further, the concentrations of cyanotoxins in the treated waters, with the exception of Daraganj Ghat and Ram ghat, remained above WHO guideline. Although ecological integrity is and must remain a holistic concept, a number of key components of the assessment procedure can be feasibility investigated and evaluated. The component as plankton and used in this assessment system include hydrology, river morphology, physicochemicals parameters, ecotoxicological aspects, biological water quality assessment, as well as microorganism and fish community (Fig. 2). The relevance of these components for an integrated river assessment is comprehensively discussed in Muhar and Jungwirth (1998) and Muhar et al., (2000). The disturbance of ecological integrity is assessed and classified within a seven-termed system (Table-1)

\section{Risk assessment of cyanotoxins}

A hazard quotient is the ratio of the potential exposure to a substance and the level at which no adverse effects are expected. Risk assessment using the intake rate, hazard quotient and hazard indices using the equations presented below, are described to determine the risk associated with drinking water contaminated with cyano-bacterial toxins.

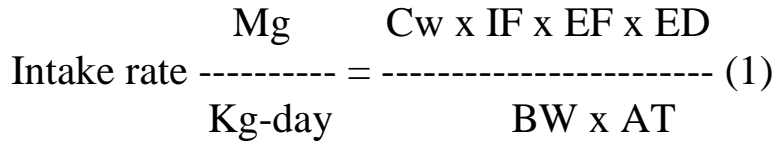

Where: $\mathrm{CW}=$ concentration in water $(\mathrm{mg} / \mathrm{l})$; $\mathrm{IF}=$ intake frequency $(\mathrm{L} / \mathrm{day}) ; \mathrm{EF}=$ exposure frequency (days); $\mathrm{ED}=$ exposure duration (years); $\mathrm{BW}=$ body weight $(\mathrm{kg}) ; \mathrm{AT}=$ average time (days)

Hazard quotient = $=\stackrel{\text { Intake Rate }}{\text { Reference Dose }}$

Where: $\mathrm{HQ}=$ hazard quotient.

The intake rate and hazard quotients for consuming raw water, water after conventional treatment in the two geographical locations are calculated using Equations 1 and 2 using the data presented in Table 4. The calculation conditions below are used in deriving Tables 5 and 6 .

\section{Key assumptions}

Body weight for adult, $70 \mathrm{~kg}$.

Body weight for a baby, $10 \mathrm{~kg}$.

Water ingestion rate for an adult is 2 L/day- 4 L/day.

Water ingestion rate for a ten-month-old baby is $0.24 \mathrm{~L} /$ day.

Unintentional ingestion is $1.5 \mathrm{~L} /$ day.

Exposure frequency is 182 days for an adult and a baby. 
Exposure frequency is 365 days for an adult and a baby.

The reference dose for an adult is 0.0001 for both water (Ohio State Environmental Protection Agency, 2013).

Reference dose for a baby is $(10 \mathrm{~kg} / 70 \mathrm{~kg} \mathrm{x}$ $0.0001)=1.43 \times 10^{-5 \mathrm{mg} / \mathrm{L}}$ per day

The cyanobacteria toxins in the assumed intake are derived only from water

Conventional drinking water treatment plant removal efficiency for cyanobacteria toxins was between $25 \%$ for small drinking water treatment plants in Nigeria (Mouchet and Bonnélye, 1998).

\section{Results and Discussion}

Table 2 showed the hydrological status of study site which are raw resource for cyanotoxin. The value for turbidity, ammonia, BOD, was high at Sangam. The high Turbidity at Sangam followed by Yamuna and Ganga, it is due to sand particle and heavy phyto bloom, respectively. The diurnal variations of DO with BOD showed that the maximum bathing took place, the organic load and Faecal coliform density was directly propotional and that had was maximum at Sangam in comparison to Ganga and Yamna because of intense bathing activity is confined area, data presented (Dwivedi et al., 2012; Dwivedi and Srivastava et al., 2015; Dwivedi, 2016 ab). Total hardness was also positively correlated with turbidity and chloride, conductivity. In the study high value of nitrate and phosphate were recorded in Yamuna followed by Ganga and Yamuna, which gradually decline in efficient water flow. Due to a greater level in organic loading at the confluence and localizes human interference maximum activity is reported from the confluence which also has highest microbial count (Dwivedi et al., 2012) therefore, indicating a great degree of pollution via organic loading at this site (Dwivedi and Srivastava, 2017a,b).

High nutrient influx and toxin producing algal species have been observed period during study period. In Yamuna river at Allahabad city (before Sangam) Microcystis species (Microcystis protocystis. $M$. aeruginosa, $M$. lotoralis, $M$. incerta, $M$. princeps) constitute > $50 \% 0$ of the biomass and in Sangam toxin producing algal species share of the biomass rose towards the end of summer season $<50 \%$ followed by (Dwivedi, 2016c,d).

Table 5 summarizes the hazard quotient (the ratio of the potential exposure to a substance and the level at which no adverse effects are expected) of raw water an adult and a baby drinking raw water.

From the hazard quotient values presented in Table 5, the results indicate that the Ram ghat is the only safe drinking water in terms of microcystins. Table 5 presents a summary that relates the hazard index of treated drinking water for an adult and a baby to the water treatment technology used drinking water treatment plants; from the hazard quotient values presented in Table 6 , the results indicate that a combination of conventional treatment and membrane filtration which is used in Ram ghat is an efficient technique for removing cyanotoxins.

Table 5 presents a summary that relates the hazard index of treated drinking water for an adult and a baby to the water treatment technology used drinking water treatment plants; from the hazard quotient values presented in Table 6 , the results indicate that a combination of conventional treatment and membrane filtration which is used in Ram Ghat is an efficient technique for removing cyanotoxins. 
Fig.1 Map showing five sites along the Ganga River in Allahabad city. Site1-Rasoolabad Ghat, Site2- Daraganj Ghat, Site3- Ram Ghat, Site4-Sangam and Site 5-Chhatnag Ghat

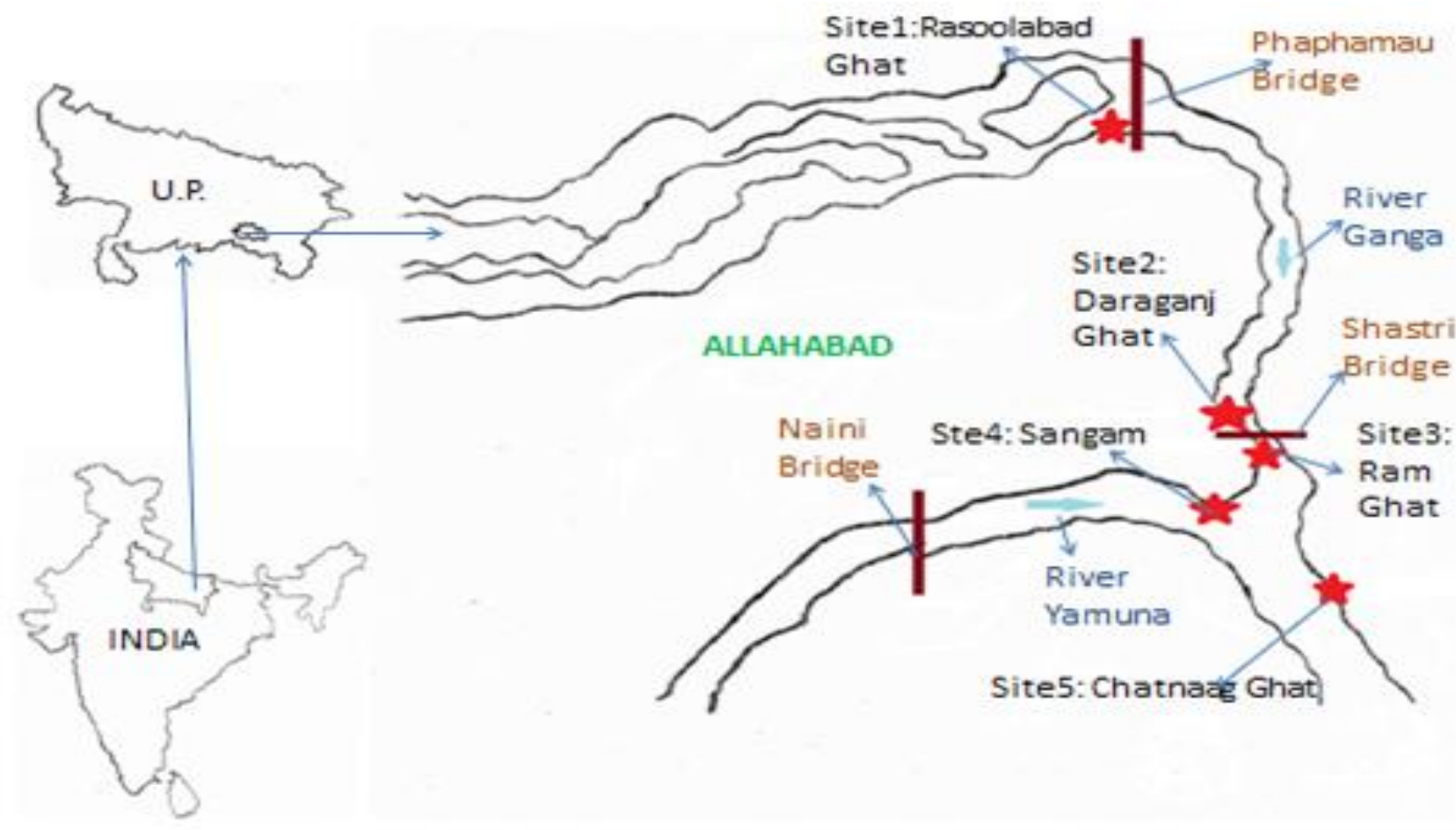

Fig.2 Criteria for assessing the ecological integrity of running water

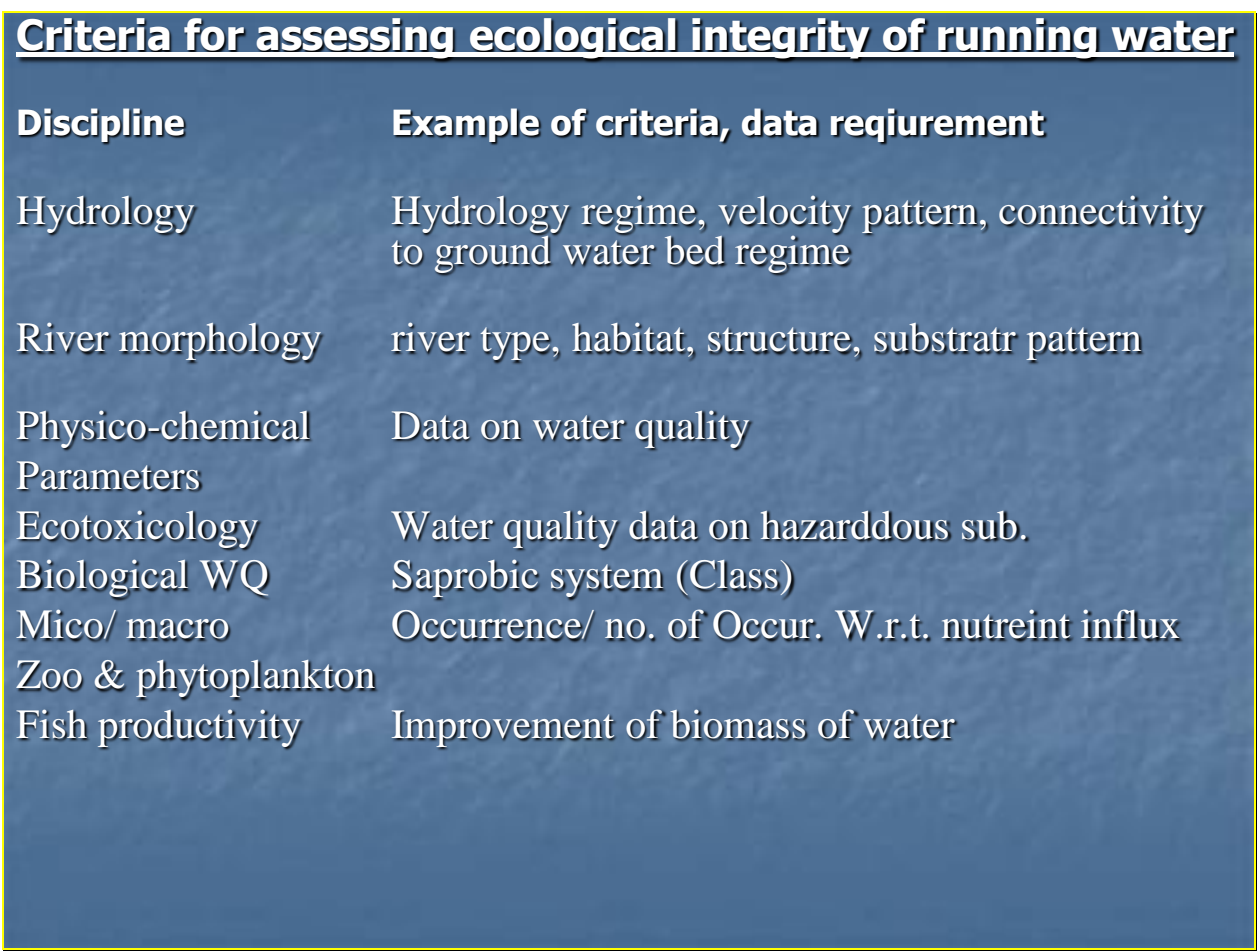


Table.1 Seven class evaluation of the ecological integrity of running water

\begin{tabular}{ll} 
Class & Ecological Integrity \\
1 & undisturbed \\
$1-2$ & slightly disturbed \\
2 & Moderately disturbed \\
$2-3$ & significantly \\
3 & heavily disturbed \\
$3-4$ & very heavily disturbed \\
4 & completely disturbed \\
\hline
\end{tabular}

Table.2 Physico-Chemical parameters of water quality at Ganga, Yamuna \& Sangam at Allahabad

\begin{tabular}{llllllllcc} 
S. No. Parameters & \multicolumn{1}{c}{ Water Quality } \\
\cline { 2 - 10 } & \multicolumn{1}{l}{ Ganga river } & \multicolumn{3}{c}{ Yamuna } & \multicolumn{3}{c}{ Sangam } \\
\cline { 2 - 9 } 1. Water Temp. & 20.50 & 20.90 & 20.70 & 20.80 & 20.00 & 20.40 & 18.20 & 20.00 & 19.10 \\
2. Air Temp. & 20.80 & 20.90 & 20.85 & 20.50 & 20.50 & 20.50 & 20.20 & 20.00 & 2010 \\
3. pH & 07.40 & 08.00 & 07.60 & 07.34 & 07.26 & 07.30 & 07.42 & 07.68 & 07.55 \\
4. Conductivity & 34.82 & 35.22 & 35.02 & 28.42 & 32.28 & 30.30 & 34.12 & 40.28 & 37.20 \\
5. Turbidity & 18.00 & 21.00 & 19.05 & 71.00 & 73.00 & 72.00 & 13.04 & 14.00 & 13.20 \\
6 Hardness & 219.06 & 345.4 & 282.5 & 188.0 & 192.1 & 185.0 & 201.0 & 234.0 & 217.5 \\
7. DO & 04.20 & 05.40 & 04.88 & 04.00 & 04.04 & 04.44 & 04.60 & 04.88 & 04.74 \\
8. BOD & 07.08 & 08.00 & 07.90 & 07.60 & 07.88 & 07.74 & 08.56 & 09.40 & 08.98 \\
9. Chloride & 24.05 & 37.05 & 36.00 & 78.05 & 54.05 & 53.05 & 24.00 & 29.00 & 26.00 \\
10. Ammonia & 1.98 & 01.99 & 01.98 & 02.54 & 03.16 & 02.93 & 04.10 & 04.07 & 04.93 \\
11. Nitrate & 14.00 & 14.88 & 14.44 & 13.60 & 13.88 & 13.74 & 14.20 & 15.40 & 14.88 \\
12. Phosphate & 14.00 & 14.88 & 14.44 & 13.60 & 13.88 & 13.74 & 14.20 & 15.40 & 14.88
\end{tabular}

Except Temperature $\left({ }^{\circ} \mathrm{C}\right), \mathrm{pH}$, conductivity $\left(\mathrm{mhos} \mathrm{cm}^{-1}\right)$ and Turbidity (NTU) all values are in $\mathrm{mg} / \mathrm{l}$ (Mean \pm SEM of three replicate)

Table.3 Concentrations of cyanotoxins in raw and treated water

\begin{tabular}{lcc}
\hline Location & Raw water $(\mu \mathrm{g} / \mathrm{L})$ & Treated water $(\boldsymbol{\mu g} / \mathbf{L})$ \\
\hline Rasoolabad Ghat & 105.5 & 22.47 \\
Daraganj Ghat & 18.54 & 3.155 \\
Ram Ghat & 3.99 & 1.077 \\
Sangam & 13.76 & 3.8 \\
Chhatnag Ghat & 22.4 & 11.68 \\
\hline
\end{tabular}

Table.4 Reference daily doses

\begin{tabular}{ll}
\hline Food & Cyano-toxin \\
\hline Reference daily dose for an adult & $0.001 \mathrm{mg} / \mathrm{L}$ \\
& 1.43 \\
& $x^{-5} \mathrm{mg} / \mathrm{L}$ \\
\hline
\end{tabular}


Table.5 Hazard quotient summary for an adult and a baby consuming raw water

\begin{tabular}{lll}
\hline Location & $\begin{array}{l}\text { Hazard quotient for an } \\
\text { adult }\end{array}$ & $\begin{array}{l}\text { Hazard quotient for a } \\
\text { baby }\end{array}$ \\
\hline Rasoolabad & & \\
Ghat & 33.9 & 197 \\
Daraganj Ghat & 4.2 & 24.5 \\
Ram Ghat & 0.03 & 0.18 \\
Sangam & 2.17 & 6.3 \\
Chhatnag Ghat & 1.3 & 3.9 \\
\hline
\end{tabular}

Table.6 Hazard quotient summary for an adult and a baby consuming treated water

\begin{tabular}{llcc}
\hline Location & Water treatment technology & $\begin{array}{c}\text { Hazard quotient } \\
\text { for an adult }\end{array}$ & $\begin{array}{c}\text { Hazard quotient } \\
\text { for a baby }\end{array}$ \\
\hline Rasoolabad & Conventional Treatment & 02.8 & 08.77 \\
& and chlorination & & 03.26 \\
& Conventional Treatment & 02.66 & 02.82 \\
Daraganj & and chlorination) & & 06.6 \\
Ram ghat & Conventional treatment, sedimentation and & 4.87 & 04.9 \\
Sangam & Riverbank filtration, sedimentation and chlorination & 09.5 & 02.45 \\
Chhatnag & Sand filtration, sedimentation and chlorination & & \\
\hline
\end{tabular}

Table 3 was used together with Equations 1, 2 , and 3 to calculate the non-carcinogenic risk for a person that weighs $70 \mathrm{~kg}$ a- $4 \mathrm{~L}$ of water daily. The individual drank directly from the contaminated lake. Furthermore, the same approach is performed for a baby that weighs $10 \mathrm{~kg}$ and drinks $0.24 \mathrm{~L}$ of water per day. A hazard quotient is the ratio of the potential exposure to a substance and the level at which no adverse effects are expected. The hazard quotients for an adult and a baby consuming raw water are summarized in Table 4.

The hazard quotients for an adult and a baby consuming treated drinking water is presented in Table 5; for an adult in Rasoolabad ghat, Sangam and Chhatnag ghat treated drinking water the hazard quotient is greater than one, while for an adult in Daraganj ghat and Ram gaht consuming treated drinking water, the hazard quotient is less than one. Similarly, the hazard quotient result for a baby consuming treated drinking water in Rasoolabad ghat, sanagam and Chhatnag ghat exceeds 1 , while for a baby consuming treated water in Daraganj ghat and Ram ghat, the hazard quotient is less than one.

The presences of cyanotoxins in treated drinking water supply from small water treatment plants reaffirms the need to assess the risk of cyanotoxins from these small water treatment plants. In this study, the hazard quotients for an adult and a baby were calculated for a single exposure of treated water for the five treatment plants. The summary calculations are shown in Table 4. The results indicate that a combination of 
conventional treatment and membrane filtration used in Ram ghat (Table 5) is an efficient technique for removing cyanotoxins. The other water treatment plants that use combination of coagulation, activated carbon, oxidation, clarification and chlorination have shown a high percentage of removal of cyanotoxins (greater than 97\%). This highlights the importance of adopting more efficient water treatment technologies in affected areas to minimize the risk to a human receptor. The people living in these two communities are exposed to elevated concentration of toxin in their drinking water supply.

The results in the different communities included in this study show clearly that hazard quotient for babies are much higher than that for adults. Excluding ram ghat community, the increased risk for babies compared to adults is between 1.6 and 4.1 to all other four communities. Moreover, all the results above were calculated based on a single exposure (drinking water). Therefore, it is expected that the risk index, which is defined as the sum of hazard quotients due to different exposures, is also alarming. Other exposures that were not considered in this study are food crops irrigated with cyanotoxins-contaminated water, inhalation of water aerosols, and other water sports like swimming and surfing (Queensland Health, 2001).

The assessment of the cyanotoxin removal capacity for small water treatment plants shows that the concentrations of cyanobacterial toxins in treated drinking water is concern; the hazard quotient derived from a combination of treated or untreated water from drinking water treatment plants in in Allahabad city exceeded unity which indicates the need for appropriate remedial action to be taken or an alternative water supply developed. Also, the intake rate exceeded the recommended World Health
Organization intake guideline of $1 \mu \mathrm{g} / \mathrm{L}$. Applicable strategies to eliminate cyanobacteria blooms would be appropriate to adopt for water treatment facilities in Allahabad city in order to protect consumer's health. A more sustainable strategy that consists of reducing the introduction of nutrients in surface waters is ideal for a longterm solution. Advanced water treatment techniques such as membrane filtration should be adopted since they have been proven to be very effective in treating all kinds of organic contaminants. Small drinking water treatment plants can be upgraded to include membrane filtration and ozonation. This will help to achieve high removal efficiency.

These running water ecological integrity are being incorporated into the urban critical deficits water supply/ treatment infrastructure in view of their religious and ecological importance to human welfare. These findings emphasis the importance of catchment management to reduce nutrient inputs, in addition to in-water reservoir (possibly through sediments reduction) as part of a suite of approaches, including biomanipulation, for restoration of eutrophic reservoir in general and running water at Allahabad city for no risk of cyanotoxin.

\section{Acknowledgement}

The authors are extremely grateful to the Coordinator, Environmental Science, Botany Department, University of Allahabad, for the support and encouragement during the course of this work.

\section{References}

APHA, AWWA and WPCT, 2010. Standard methods for examination of waste water, $27^{\text {th }}$ edition American health association water works association and water pollution control fedration, New 
York.

Asnaashari A. B., Gharabaghi,. McBean, A. A. Mahboubi, 2015. Reservoir Management Under Predictable Climate Variability and Change. J. Water Climate Change 6(3):472-485.

Baker L. C., D. Manassaram-Baptiste, R. LePrell, B. Bolton, 2015. Cyanobacterial and algae blooms: Review of health and environmental data from the harmful algal bloomrelated illness. surveillance system (HABISS) 2007-2011. Toxins 7:10481064.

Ballot A., J. Fastern, C. Wiedner, 2010. Paralytic shellfish toxin-producing Cyanobacterium. Alphanizomenon gracile in Noeast Germany. Appl. Environ. Microbiol. 76:1173-180.

Baxa D.V., T. Kurobe, K.A. Ger, P.W. Lehman, 2010. Estimating the abundance of toxic microcystins in San Francisco Esturay using qualitative realtime PCR. Harmful algae 9:342-349.

Benedini M., G. Tsakiris, 2013. Water quality modelling for rivers and streams. Springer Science \& Business Media, Dordrecht.

Bogialli, S.F., L. Nigro Di Gregorio, E. Lucentini, M. Ferretti, N. Ottaviani, N. Ungaro, P.P. Abis, M. Cannarozzi DeGrazia, 2013. Management of toxic Cyanobacterium bloom (Planktothrix rubescens) affecting an Italian drinking water basin: A case study. Environ. Sci. Technol. 47:574-583.

Chanson H., 2004. Environmental hydraulics for open channel flows. Elsevier, Oxford.

Chia A., D. Abolude, Z. Laden, O. Akanbi, A. Kalabonus, 2009. The presence of Microcyctins in Aquatic ecosystems in Northern Nigeria: Zaria as a Case Study. Resour. Environ. 3(4):170-178.

Chia M.A, M.J. Kwaghe, (2015. Microcyctins Microcystins contamination of surface water supply sources in Zaria-Nigeria. Environ. Monitor. Assess. 187:10.1007/s10661-015-4829-3.

Chorus I, I.R. Falconer, H.J. Salas, J. Bartram, 2000. Health Risks Caused By Freshwater Cyanobacteria In Recreational Waters. J. Toxicol. Environ. Health Part B 3:323-347.

Codd G.A, J. Lindsay, F.M. Young, L.F. Morrison, J.S. Metcalf, 2005. Harmful cyanobacteria: from mass mortalities to management measures. Springer: pp. 123.

Drabkova M., B. Marsalek, 2007. A review of in-lake methods of cyanobacterial blooms control and management. CyanoData - The Glogal Database of Methods for Cyanobacterial Blooms Management, Centre for Cyanobacteria and their Toxins www.cyanodata.net

Duy T.N., P.K.S. Lam, G.R. Shaw, D.W. Connell, 2000. Toxicology and risk assessment of freshwater cyanobacterial (blue-green algal) toxins in water. Rev. Environ. Contam. Toxicol. 163:113186.

Dwivedi B.K., A. K. Srivastava, 2015. Ecological-integrity of running water at Allahabad city. Bioherald. 5(1-2), 6368.

Dwivedi, B.K. 2016a. Bio-sequestering of Hydro- biological and Nutrient transport variations in Indian river. Intl. J. Advance Research and Technology. 4(1), 11-21.

Dwivedi, B.K. 2016b. Occurrence of Cyanotoxins and their Removal by Oxygen Evolving Bacteria with Implication to Fish productivity. Current Microbiology and Applied Sciences. 5 (3), 36-47.

Dwivedi, B.K. 2016c. Ecological Integrity of River Water Quality: in Relation to Primary Productivity and Cyanotoxin Occurrence. Int. J. Adv. Biol. Sci. 3 (3), 200-207. 
Dwivedi, B.K. 2016d. Phytoplankton Primary Production in Relation to Limnochemical feature in the context of Fish Yield Potential of running Water. Int. J. Curr. Res. in Biosci. Plant. Biol. 3(4), 106-115.

Dwivedi, B.K., G. C. Pandey, 2015. Hydrochemical Assesssment of the Pollutants in Ground Waters of Allahabad city. Advance Research and Technology. 3(4), 26-35.

Dwivedi, B.K., S. P. Tiwari, D. K. Prihar, 2012. Biological Surveillance of running water at Allahabad city. Bioherald 2(1), 35-40.

Dwivedi, B.K., A. K. srivastava, 2017a. Diatoms as Indicator of Pollution Gradients of the river Ganga,

Allahabad. Int. J. Curr. Microbiol. App.Sci. 6 (7), 4323-4334.

Dwivedi, B.K., A. K. srivastava, 2017b. An approach to assess potential heavy metal in the sediments transport of river Ganga channel. Int. J. Curr. Res. in Biosci. Plant. Biol. 4(12), 106-115.

Dwivedi, B.K., G. C. Pandey, 2001. Seasonal dynamics of cyan bacterial toxin producing algal species of two water ponds. Aquacult. 2, 141-146.

Dwivedi, B.K., G. C. Pandey, 2002b. Lengthweight relationship and relative condition factors of Labeo rohita and Catla catla in Cyanotoxin Environment and its mitigation through Photosynthetic bacteria, Pro. Zoological Society of India. 1, 9-16.

Dwivedi, B.K., G. C. Pandey, 2003a. Complex dynamics of toxin producing algal species and primary productivity in two water ponds of Faizabad. Env. Biol. 24(1), 55-61.

Dwivedi, B.K., G. C. Pandey, 2003b. An approach to improve water quality through Photosynthetic bacteris. Nature Environment and and Pollution Technology, 2(2), 145-152.
Dwivedi, B.K., G.C. Pandey, 2002a. Physicochemical factors and algal diversity of two ponds (Girija Kund and Maqubara pond) Faizabad. Poll. Res.21(3), 365374.

Echenique R.O., A. Aguilera, L. Giannuzzi, 2014. Problems on drinking water related to toxigenic Cyanobacteria: Some cases studied in Argentina. Adv. Limnol. (65):431-444.

Farrer D., M. Counter, R. Hillwig, C. Cude, 2015. Health-based cyanotoxin guideline values allow for cyanotoxinbased monitoring and efficient public health response to cyanobacterial blooms. Toxins 7:457-477.

Gazendam E., B. Gharabaghi, J. Ackerman, H. Whiteley, 2016. Integrative Neural Networks Models for Stream Assessment in Restoration Projects. J. Hydrol. 536:339-350.

Griffiths D.J., M.L. Saker, 2003. The Palm Island mystery disease 20 years on: a review of research on the cyanotoxin cylindrospermopsin. Environ. Toxicol. 18:78-93.

Hans W.P., G.O. Timothy, 2013. Harmful Cyanobacterial Blooms: Causes, Consequences, and Controls. Environ. Microbiol. DOI 10.1007/s00248-0120159.

Heisler J., P.M. Glibert, J.M. Burkholder, D.M. Anderson, W. Cochlan, W.C. Dennison, Q. Dortch, C.J. Gobler C.A. Heil, E. Humphries, A. Lewitus, R. Magnien, H.G. Marshall, K. Sellner, D.A. Stockwell,, D.K. Stoecker, M. Suddleson, 2008. Eutrophication and harmful algal blooms: a scientific consensus. Harmful Algae 8:3-13.

Holzbecher E., 2012. Environmental modeling: using MATLAB. Springer, Heidelberg.

Hrudey S., M.D. Burch, M. Drikas, R. Gregory, 1999. Remedial measures. In Toxic cyanobacteria in water: a guide to 
their public health consequences, monitoring, and management. Edited by Chorus I, Bartram JE, Spon FN New York. pp. 275-312.

Kaushik R., R. Balasubramanian, 2013. Methods and Approaches for Detection of Cyanotoxins in Environmental samples: A review: Critical Rev. Environ. Sci. Technol. 43:1349-1383.

Keijola A., K. Himberg, A. Esala, K. Sivonen, L. Kiisvirata, 1989. Removal of cyanobacterial toxins in water treatment processes: laboratory and pilot plant experiments. Toxic. Assess. 3:643-656.

Kutovaya O.A., S.B. Watson, 2014. Development and application of a molecular assay to detect and monitor geosmin-producing cyanobacteria and actinomycetes in the Great Lakes. J. Great Lakes Res. 40:404-414.

Makarewicz J.C., T.W. Lewis, 2015. Exploring spatial trends and causes in Lake Ontario coastal chemistry: Nutrients and pigments. J. Great Lakes Res. 3:794-800.

Merel S., D. Walker, R. Chicana, S. Snyder, E. Baures, O. Thomas, 2012. State of Knowledge and concerns on Cyanobacterial blooms. Environ. Int. 59:303-327.

Merel S., M. Clément, O. Thomas, 2010. State of the art on Cyanotoxins in water and their behaviour towards chlorine. Toxicon 55:677-691.

Mohamed Z.A., M.A. Deyab, M.I. AbouDobara, A.K. El-Sayed, W.M. Raghi, 2015. Occurrence of cyanobacteria and microcystin toxins in raw and treated waters of the Nile River, Egypt: implication for water treatment and human health. Environ. Sci. Pollution Res. 22:11716-11727.

Mouchet P., V. Bonnélye, 1998. Solving algae problems: French expertise and worldwide applications. AQUA 47(3):125-141.
Muhar, S.,S. Schwartz, M. Jungwirth, 2000. Identification of rivers with high and good habitat quality: methodology approach and application in Austria. Hydrobiologia 422/ 423, 343-358.

Newcombe G., B.C. Nicholson, 2002. Treatment options for the saxitoxin class of Cyanotoxins. Water Sci. Technol. Water Supply 2(5-6):271-275.

Nicholson B.C., G.R. Shaw, J. Morrall, P.J. Senogles, T.A. Woods, J. Papageorgiou, C. Kapralos, W. Wickramasinghe, B.C. Davis, G.K. Eaglesham, M.R. Moore, 2003. Chlorination for degradingsaxitoxins (paralytic shellfish poisons) in water. Environ. Technol. 24(11):1341-1348.

Ohio State Environmental Protection Agency, 2013. Public Water System Harmful Algal Bloom Response Strategy 1:1-47.

Ontario Health Unit, 2014. Beach management guidance document; Ministry of health and long-term care pp. 1-16.

Ostermaier V., R. Kurmayer, 2010. Application of real-time PCR to estimate toxin production by the cyanobacterium Planktothrix sp. Appl. Environ. Microbiol. 76:3495-3502.

Paerl H.W., N.S. Hall, E. S. Calandrino, 2011. Controlling harmful cyanobacterial blooms in a world experiencing anthropogenic and climatic-induced change. Sci. Total Environ. 409:17391745.

Pandey, G.C., B. K. Dwivedi, 2002. The toxins of cyanobacteria: Emering water quality problem. In Ecology of polluted water (ed. Kumar). Asish Publishing House, New Delhi. Pp, 395-405.

Queensland Health, 2001. Environmental health assessment guidelines: Cyanobacteria in recreational and drinking wa-ters. Environmental Health Unit Bris- bane, Australia.

Sayyad G., L. Vasel, A. Besalatpour, B. 
Gharabaghi, G. Golmohammadi, 2015. Modeling Blue and Green Water Resources Availability in an Iranian Data Scare Watershed Using SWAT. J. Water Manage. Modeling doi: 10.14796/JWMM.C391.

Stang C., B. Gharabaghi, R. Rudra, A. Mahboubi, S. Ahmed, 2016. Conservation management practices success story of the Hog Creek and Sturgeon River Watersheds, Ontario, Canada. J. Soil Water Conserv. 71(3):237-248.

Szlag D., J. Sinclair, B. Southwell, J. Westrick, 2015. Cyanobacteria and Cyanotoxins Occurrence and Removal from five High-risk conventional Treatment drinking water plants. Toxins 7:2198-2220.

Tencalla F., D. Dietrich, 1997. Biochemical Characterization of Microcystin toxicity in trout (Oncorhyncnchus mykiss).
Toxicon 35:583-595.

USPHS, 1997. Toxicological profile for zinc and lead on CD-ROM. Agency for Toxic Substances and Disease Registry. U.S. Public Health Service.

Westrick J.A, D.C. Szlag, B.J. Southwell, J. Sinclair, 2010. A review of cyanobacteria and Cyanotoxins removal /inactivation in drinking water treatment. Anal. Bioanal. Chem. 397:1705-1714.

WHO, 1996. Guidelines for Drinking Water, VOL. 2, Recommendations World Health, Organization, Geneva.

Zamyadi A., L. Sherri, F. Yan, N. McQuaid, S. Dorner, S. Sauve, M. Prevost, 2012. Toxic cyanobacterial breakthrough and accumulation in a drinking water treatment plant: A monitoring and treatment Challenge. Water Res. 46:1511-1523.

\section{How to cite this article:}

Brajesh K. Dwivedi. 2018. Potential Risk Assessment of Cyanotoxin for Water Resources. Int.J.Curr.Microbiol.App.Sci. 7(02): 3604-3616. doi: https://doi.org/10.20546/ijcmas.2018.702.429 